Article

\title{
An Innovative Low-Cost Equipment for Electro-Concentration of Microalgal Biomass
}

\author{
Edwar M. Sanchez-Galvis ${ }^{1}$, Ingri Y. Cardenas-Gutierrez ${ }^{2}$, Jefferson E. Contreras-Ropero ${ }^{2}{ }^{(1)}$, \\ Janet B. García-Martínez ${ }^{2}$, Andrés F. Barajas-Solano ${ }^{2} \mathbb{D}$ and Antonio Zuorro ${ }^{3, * \mathbb{D}}$ \\ 1 Grupo Ambiental de Investigación Aplicada-GAIA, Engineering Faculty, Universidad de Santander, \\ 680003 Bucaramanga, Colombia; mauriciosanchez8711@gmail.com \\ 2 Department of Environmental Sciences, Universidad Francisco de Paula Santander, Av. Gran Colombia No. \\ 12E-96, 540003 Cucuta, Colombia; ingridyurleicg@ufps.edu.co (I.Y.C.-G.); \\ jeffersoneduardocr@ufps.edu.co (J.E.C.-R.); janetbibianagm@ufps.edu.co (J.B.G.-M.); \\ andresfernandobs@ufps.edu.co (A.F.B.-S.) \\ 3 Department of Chemical Engineering, Materials and Environment, Sapienza University, Via Eudossiana 18, \\ 00184 Roma, Italy \\ * Correspondence: antonio.zuorro@uniroma1.it
}

Received: 17 May 2020; Accepted: 8 July 2020; Published: 14 July 2020

Featured Application: This paper features the design and construction of low-cost equipment for the harvesting of microalgal and cyanobacterial biomass under laboratory conditions.

\begin{abstract}
Microalgal harvesting is one of the most challenging processes in the development of algal research and development. Several methods, such as centrifugation, flocculation and filtration, are available at the laboratory scale. However, the requirement for expensive pieces of equipment and the possibility of biomass contamination are recurring gaps that hinder the development of microalgae R\&D (research and development) in different parts of the world. Recently, electroflotation has been proved to be a suitable method for the harvesting of different species of microalgae and cyanobacteria. To this day, there are no companies that sell laboratory-scale electroflotation equipment; this is mainly due to the gap in the knowledge of which factors (time, mixing rate, number of electrodes and others) will affect the efficiency of concentration without reducing the biomass quality. This paper aims to build an innovative, low-cost electroflotation system for under 300 USD (United States dollar) with cheap and resistant materials. To achieve our goal, we tested the interaction of three variables (time, mixing rate and amount of electrodes). Results showed that an efficiency closer to $100 \%$ could be achieved in under $20 \mathrm{~min}$ using $>10$ electrodes and $150 \mathrm{rpm}$ (round per minute). We hope this innovative approach can be used by different researchers to improve our knowledge of the concentration and harvesting of algae and cyanobacteria.
\end{abstract}

Keywords: dewatering; response surface methodology; Arduino; aluminum electrodes; microalgae harvesting

\section{Introduction}

The R\&D (research and development) on microalgal usage has expanded tremendously over the last two decades. From biofuels to nutraceuticals, this microorganism has led an industrial expansion of novel products for different markets worldwide. Microalgae cells are tiny, usually ranging from one to ten micrometers with a low specific gravity (1-1.1 g/L) [1], and when produced in large-scale reactors (such as open ponds or Photobioreactors), they tend to be highly diluted (on the order of 1 to $2 \mathrm{~g} / \mathrm{L}$ ) [2,3].

Given its nature, the most troublesome step of microalgae research and production is the concentration and dewatering of produced biomass. This process is a labor-intensive and time-intensive 
step, which separates the microalgal biomass from water for effective downstream processing [4]. Algae concentration and separation from the exhausted media demands large amounts of energy [5]; therefore, extended operation times are required to concentrate significant amounts of biomass.

In a broad view, in the last ten years, over 1100 research papers focused on algal production and metabolite extraction have been published. To the author's knowledge, the vast majority of these papers used centrifuges for algae concentration. Other technologies for algal concentration, such as flocculation (auto-, bio- or microbial flocculation), flotation, filtration, etc., exist; however, flocs collected may contain a certain amount of flocculant (organic or inorganic), which in turn may contaminate the final biomass, thus reducing the suitability of produced biomass for some purposes [6].

In 2018, the National Alliance for Advanced Biofuels and Bioproducts (NAABB) in its final report [7] recommended that electroflotation was the most efficient and sustainable method for algae concentration and dewatering. There are three established electrolytic methods: electrocoagulation, electroflotation and electroflocculation. This physical/chemical process is founded on the principle of the movement of electrically charged particles in an electric field [4] and the in situ generation of flocculants during metal electrolysis [8].

Briefly, an electric current is applied to the solution between two electrodes; then, metal ions are released from the sacrificial anode through electrolytic oxidation. At the same time, oxygen and hydrogen microbubbles generated at the anode and cathode flow through the suspension [9]. Metal ions react with the pollutants, forming flocs, which in turn can be lifted to the surface by the microbubbles or sediment in the lower part of the reactor $[6,10,11]$ and can be easily removed from the system's surface [12].

In 2018 [13], we proposed an Arduino-based magnetic stirrer for the harvesting of biomass through electroflotation. In this study, we found that a short distance between electrodes, medium mixing rates (200 rpm (round per minute)) and $50 \mathrm{~W}$ could remove up to $100 \%$ of algal biomass from $500 \mathrm{~mL}$ of culture media. Other authors have studied potential variables such as voltage, $\mathrm{pH}$, time, current intensity, electrode material, temperature and submerged area of electrodes. Each one of those experiments employed inexpensive materials and equipment found in most laboratories around the world (glass beakers, magnetic stirrer, power supply and lab stands) [1,3-6,8,13]. Despite its simplicity, there is no available equipment for the concentration and harvesting of algal biomass through electroflotation. This may occur because there is no consensus on which are the most critical variables for biomass concentration, which makes it challenging to build equipment that can be used for different species of both microalgae and cyanobacteria.

The aim of this project is to design and build efficient, low-cost (<300 USD (United States dollar)) electroflotation equipment for the concentration and dewatering of algal biomass. To achieve the above, the interaction of three key factors (number of electrodes, mixing rate and time) was employed.

\section{Materials and Methods}

\subsection{Strain Culture}

Scenedesmus sp. UFPS_002 was obtained for the INNOValgae collection (Universidad Francisco de Paula Santander, Cúcuta, Colombia). The strain was grown in $2000 \mathrm{~mL}$ tubular glass reactors with a culture volume of $1300 \mathrm{~mL}$ containing Bold Basal Medium [14]. The alga was mixed through the injection of air with $1 \%(v / v) \mathrm{CO}_{2}$ at a flow rate of $0.78 \mathrm{~L} / \mathrm{min}$ and a light:dark cycle of $12: 12 \mathrm{~h}$ at $120 \mu \mathrm{mol} /\left(\mathrm{m}^{2} \mathrm{~s}\right)$.

\subsection{Response-Surface Methodology for Variable Evaluation}

The interaction between three critical variables in the process was evaluated using a $3^{3}$ ( 3 factors, 3 levels) nonfactorial response-surface design with two central points on STATISTICA 7.0 software (7.0, Statsoft, Tulsa, OK, United States, 2004) (Table 1). 
Table 1. Variables for electroflotation of algal biomass.

\begin{tabular}{cccc}
\hline Level & \# of Electrodes & Mixing (rpm) & Time (min) \\
\hline-1 & 2 & 100 & 10 \\
0 & 4 & 150 & 15 \\
1 & 6 & 200 & 20 \\
\hline \multicolumn{4}{c}{ rpm: round per minute. }
\end{tabular}

Each of the experiments was performed using $300 \mathrm{~mL}$ of 30-day-old algae culture in a $600 \mathrm{~mL}$ beaker. Aluminum electrodes ( $13 \mathrm{~cm}$ long, $5 \mathrm{~cm}$ wide), with a distance of $5 \mathrm{~mm}$ between electrodes and an electric current of $50 \mathrm{~W}$ ( $50 \mathrm{~V}, 1 \mathrm{amp}$ ), were employed. To avoid deviations by electrode degradation, every single experiment was performed using new electrodes. All the samples were mixed using an Arduino-based magnetic stirrer described by [13].

The efficiency of cell concentration was determined by optical density $(550 \mathrm{~nm})$ of the culture. Each experiment was measured five times (original and four replicates). The efficiency was obtained by replacing the values obtained in Equation (1).

$$
\% \text { Ef ficiency }=100-\left\{\left(\text { final } O D_{550 \mathrm{~nm}} \times 100\right) / \text { Initial } O D_{550 \mathrm{~mm}}\right\}
$$

Once the factors affecting the process were obtained, the stability of the method was evaluated by increasing the reaction volume to $2000 \mathrm{~mL}$. In this stage, the electrodes were reused up to 20 cycles.

At the end of every cycle, the electrodes were washed with deionized water, dried in an oven $\left(100{ }^{\circ} \mathrm{C}, 24 \mathrm{~h}\right)$ and stored in a desiccator until a constant weight was obtained. After the process, the weight of each electrode was recorded, and it was used again until 20 cycles were achieved.

From the results, a system was designed to fit the needs of a microalgae-culture laboratory. The following parameters were taken into account:

- maximum efficiency of cell concentration.

- minimum working volume of $500 \mathrm{~mL}$ and maximum of $2000 \mathrm{~mL}$.

- Easy cleaning and maintenance.

- $\quad$ Final cost of less than 300 USD.

\section{Results}

From all the experiments, it was possible to retrieve the concentrated biomass. However, there were significant differences between the experiments. Table 2 presents the results for biomass concentration and temperature of the media. There was a considerable increase in temperature $\left(>35^{\circ} \mathrm{C}\right)$ in those experiments with efficiencies below $40 \%$. This increase in the temperature of the medium can have adverse effects on the stability and quality of the biomass. However, Test 5 showed efficiency values below $20 \%$, but with a temperature below $30^{\circ} \mathrm{C}$; this is due to the short time of exposure to the process in the experiment $(6.6 \mathrm{~min})$. According to [15], the distance between electrodes affects the overall energy consumption in the process. Our findings showed that not only the distance but the number of electrodes used could increase energy consumption (fewer electrodes, higher energy consumption).

The experimental data concerning the number of electrodes, mixing rate and time on the concentration efficiency of the alga was fitted to two different models: linear (L) and quadratic (Q). The Pareto analysis (Figure 1a) illustrates that $(p=0.05)$ the number of electrodes and agitation were the variables that most affected the concentration process. These results are consistent with the results presented by [16], where they demonstrated that the number of electrodes and agitation were critical variables for increasing efficiency since they allowed for increasing the active area of contact with the media and decreasing the electrical consumption. 
Table 2. The efficiency of algae concentration and temperature of media.

\begin{tabular}{|c|c|c|}
\hline Experimen & \# of Electrodes & Mixing (rpm) \\
\hline $5(\mathrm{C})$ & 4 & 150 \\
\hline 1 & 2 & 100 \\
\hline 16 & 4 & 150 \\
\hline 3 & 6 & 100 \\
\hline 15 & 4 & 150 \\
\hline 8 & 6 & 100 \\
\hline 13 & 4 & 66 \\
\hline $17(\mathrm{C})$ & 4 & 150 \\
\hline $10(\mathrm{C})$ & 4 & 150 \\
\hline 12 & 7 & 150 \\
\hline 11 & 1 & 150 \\
\hline 4 & 6 & 200 \\
\hline 2 & 2 & 200 \\
\hline 9 & 6 & 200 \\
\hline 7 & 2 & 200 \\
\hline 14 & 4 & 234 \\
\hline 6 & 2 & 100 \\
\hline \multicolumn{3}{|c|}{ 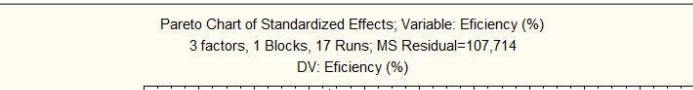 } \\
\hline \multicolumn{3}{|l|}{ (1) \# f e electrodes(L) } \\
\hline Mixing (rpm)(Q) & 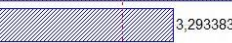 & \\
\hline \multicolumn{3}{|l|}{$\begin{array}{l}\text { Mixing }(\mathrm{rpm})(\mathrm{Q}) \\
\text { \# of electrodes }(\mathrm{Q})\end{array}$} \\
\hline \multicolumn{3}{|l|}{ (3)Time (min)(L) } \\
\hline \multicolumn{3}{|l|}{ (2)Mixing (rpm)(L) } \\
\hline \multicolumn{3}{|l|}{ 1Lby2L } \\
\hline \multicolumn{3}{|l|}{ 1Lby3L } \\
\hline \multicolumn{3}{|l|}{ 2Lby3L } \\
\hline Time (min) $(Q)$ & 象 4662166 & \\
\hline & $\begin{array}{c}\mathrm{p}=0,05 \\
\text { Standardzed Effec }\end{array}$ & solute Value) \\
\hline
\end{tabular}

(a)

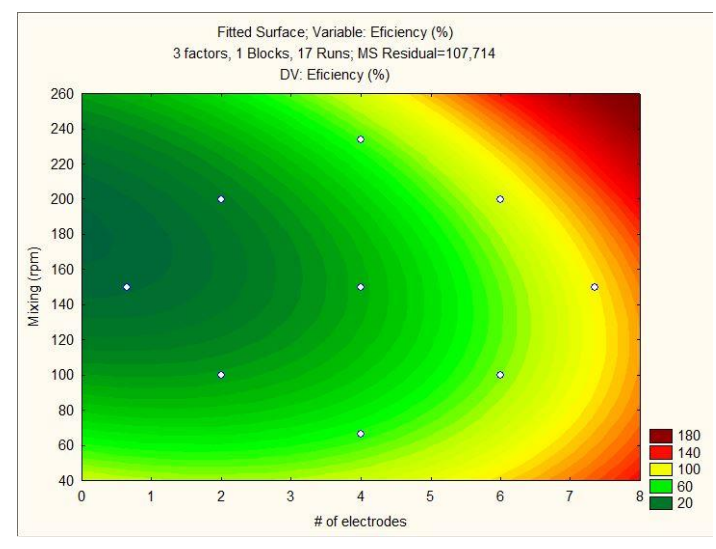

(b)

Figure 1. Pareto analysis of variables (a) and surface response between the most critical variables, mixing and number of electrodes $(\mathbf{b})$.

By analyzing the interaction between mixing and the number of electrodes (Figure 1b), Equation (2) was obtained, where $X$ is the number of electrodes and $Y$ is the mixing. These operating conditions are consistent with the results obtained by [16], where mixing had a direct relationship with the time of concentration since at speeds between 150 and $210 \mathrm{rpm}$, the biomass is aggregated in less time, with an efficiency of $90 \%$. However, they recommended the use of agitation close to $150 \mathrm{rpm}$ to save energy and maintain higher efficiencies.

$$
\begin{aligned}
Z & =(113.95380840859-19.831858022329 \times x)+\left(1.6873545265373 \times x^{2}\right) \\
& -(1.1075487762423 \times y)+\left(0.0040985935670895 \times y^{2}\right) \\
& +(0.063990154865979 \times x \times y)+(0.52423368517838 \times 15.0 \times x) \\
& -(0.018090880853718 \times 15,0 \times y)+(13.9657675)
\end{aligned}
$$

The verification of the proposed operating conditions for the efficient concentration of the biomass was tested using different volumes of culture media $(0.6,1,1.5$ and $2 \mathrm{~L})$. Results are presented in Figure 2a. 


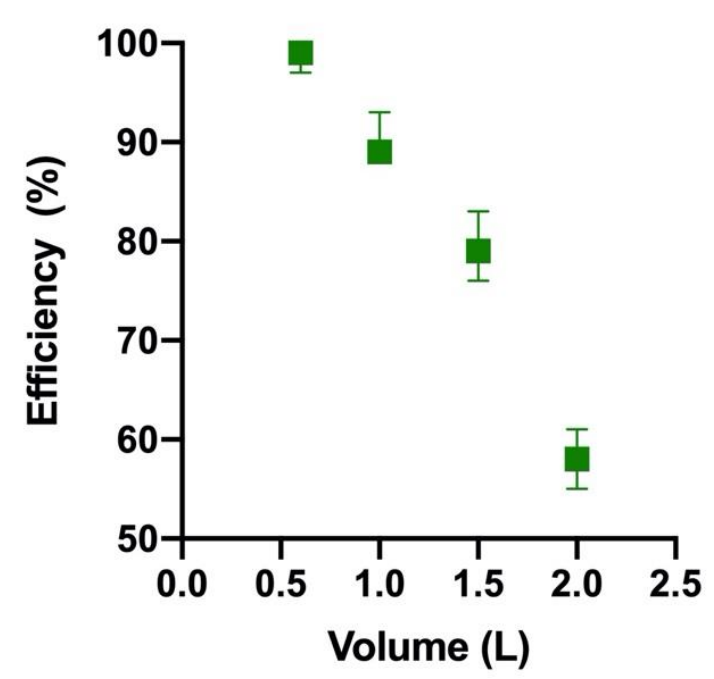

(a)

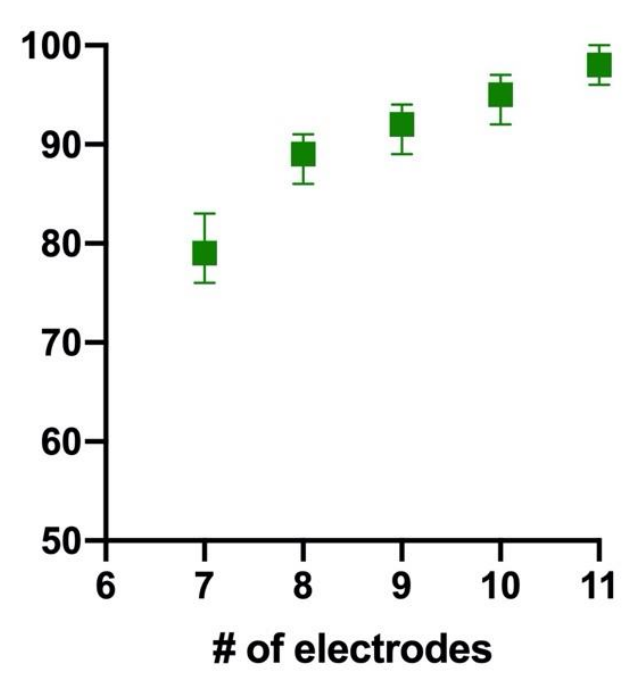

(b)

Figure 2. Efficiency of concentration using different volumes of algae culture (a) and different numbers of electrodes (b) at $150 \mathrm{rpm}$ and 6 electrodes.

As the volume of algae increased, the efficiency was substantially reduced. Another factor that can affect this is the geometry of the reactor in which the experiments were carried out. However, neither of these two variables (volume and geometry) has been previously reported in the literature.

Loss of efficiency due to increased volume is a problem that can hamper the viability of electroflotation for algae harvesting. Therefore, to demonstrate its stability, we carried out a couple of experiments, increasing the number of electrodes (with volume constant at $2 \mathrm{~L}$ ) until obtaining the desired efficiency. Figure $2 b$ shows the results for these experiments.

The verification of the proposed operating conditions for the efficient concentration of the biomass was tested.

The new operating conditions (11 electrodes, $150 \mathrm{rpm}, 20 \mathrm{~min}$ ) were tested, and a piece of innovative equipment was designed and built for the project. This new equipment has a built-in, Arduino-based magnetic stirrer at the bottom, with a working volume of 2L (Figure 3). The design of each section, the size of the electrodes and the electrical blueprint of the magnetic stirrer can be found in Appendix A, Appendix B, Appendix C. The stability of the electrodes was evaluated during 20 concentration cycles using $2 \mathrm{~L}$ of Scenedesmus sp.

After $15 \mathrm{~min}$, the process reached an efficiency of $100 \%$, with no increase in the temperature of the media (Figure 3). This process was repeated 20 times. According to the results presented in Figure 4 , it was possible to determine that, after 20 cycles, the electrodes could lose up to $15 \%(w / w)$ of their mass. These results allowed for inferring that, on average, each electrode could lose $0.57 \%$ $(w / w)$ of its weight for each liter processed. However, the efficiency of each of the cycles was above $95 \%$ (Figure 4), with no reduction in its effectiveness. The above demonstrates that electroflotation is a stable, repeatable process and that the electrodes can withstand several cycles without the need to replace them in short periods. This equipment had a cost of 260 USD. All the parts and where to buy them can be found in Appendix D. 


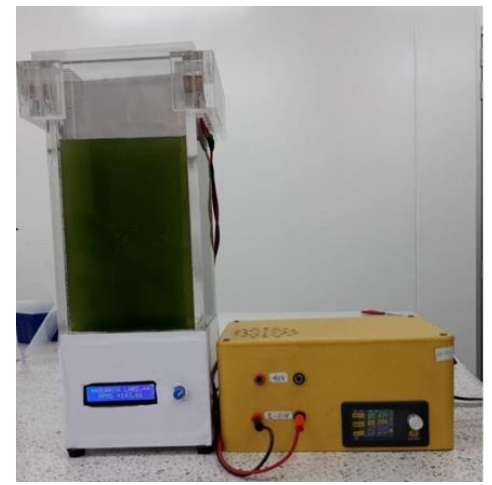

Min 0

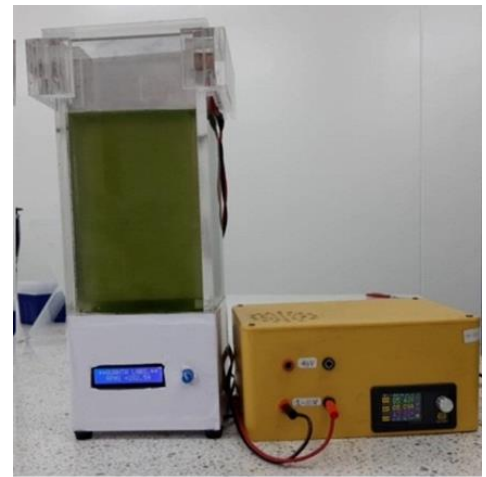

Min 6

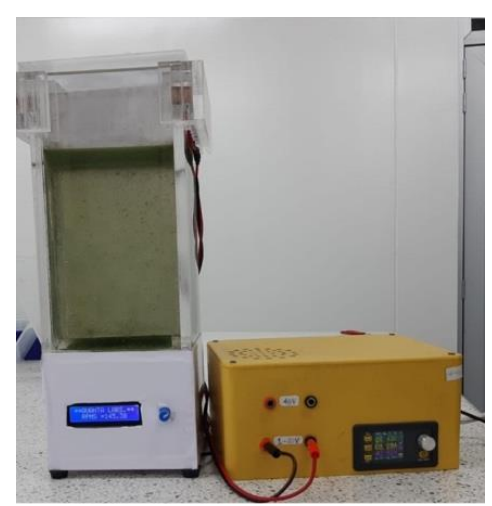

Min 12

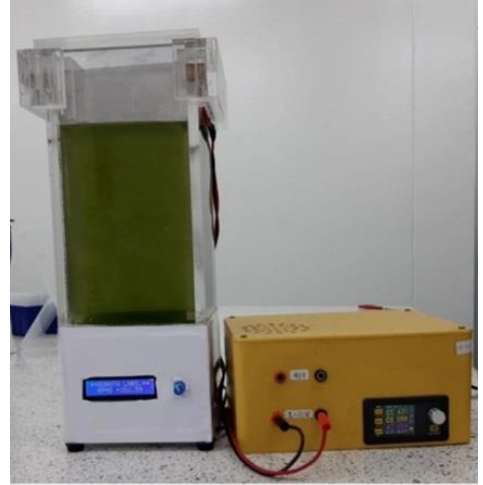

Min 2

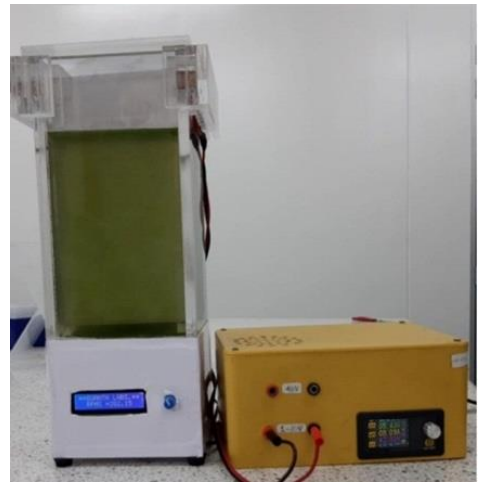

Min 8

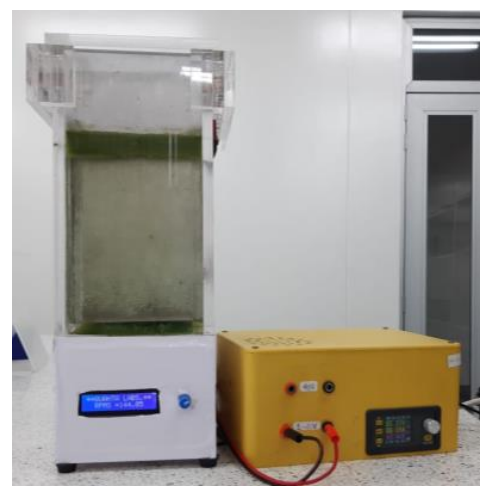

Min 15

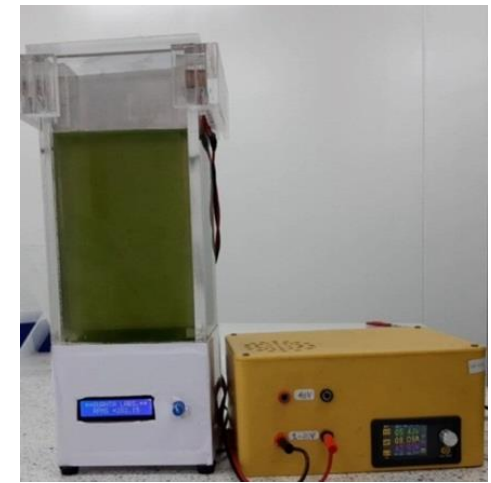

Min 4

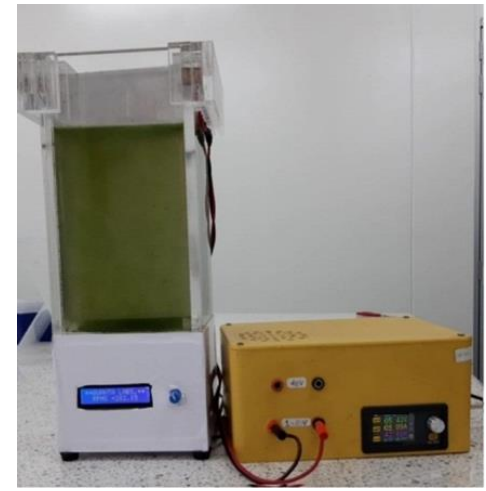

Min 10

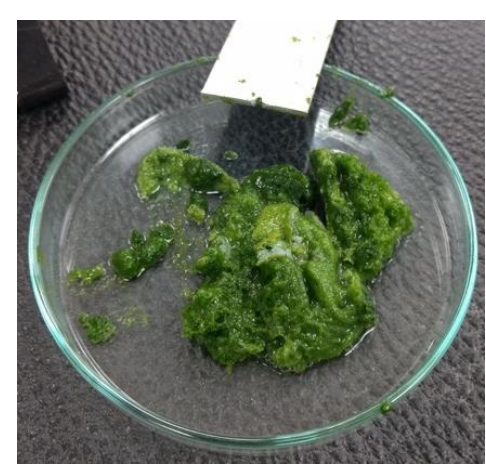

Harvested biomass

Figure 3. The concentration of biomass using the new equipment for electroflotation. 


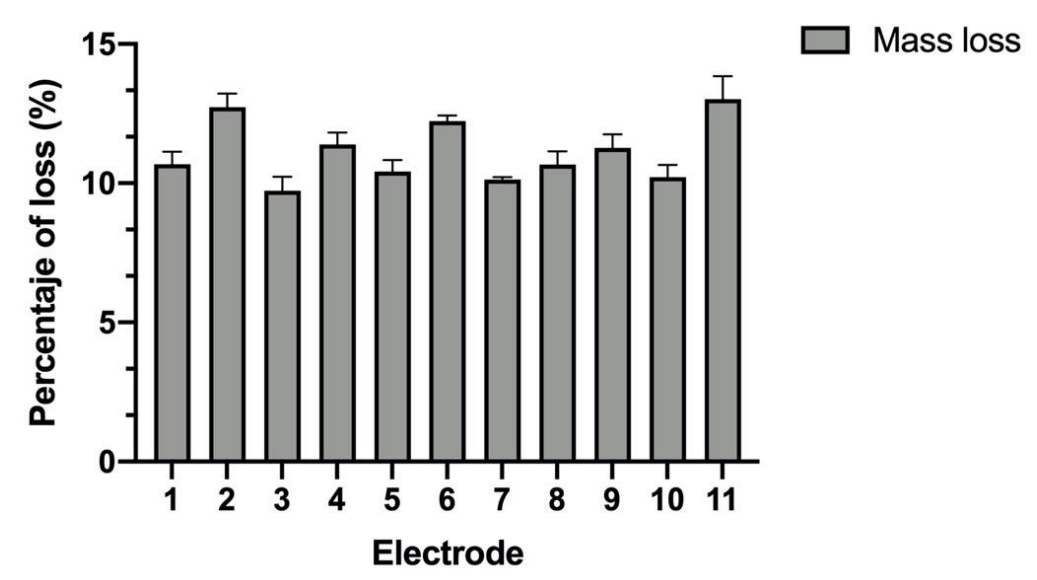

(a)

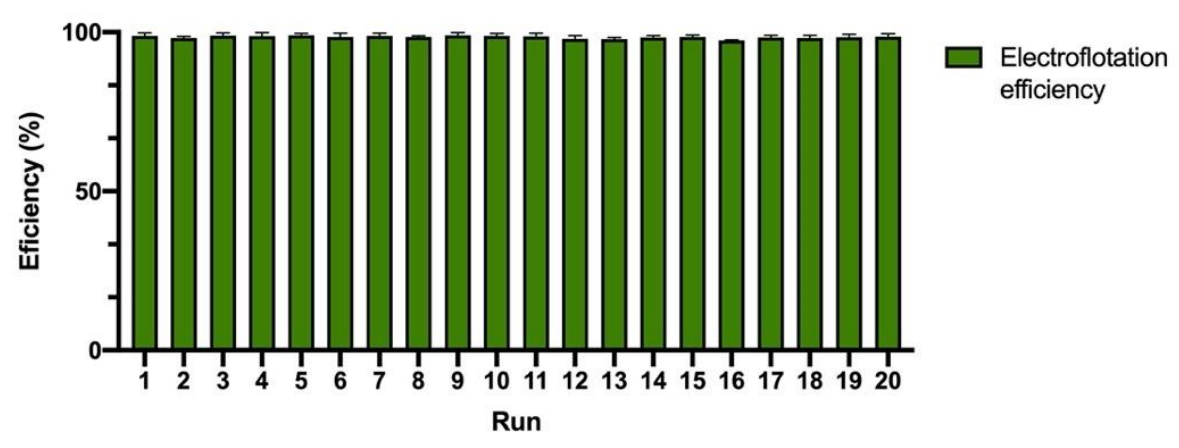

(b)

Figure 4. Mass loss of the electrodes (a) and efficiency of electroflotation by the reuse of electrodes (b).

\section{Discussion}

For the proper concentration of algal biomass, mixing of the media is required to improve cell-electrode interaction, which in turn increases the floc formation [16]. Other authors, such as [17], found that this variable did not affect the efficiency of algal harvesting. In the present work, we found that mixing affected the concentration of algal biomass positively, without a high increase in temperature. The only variable that did not affect it (either positively or negatively) was time. However, longer times (>30 min) could eventually increase energy consumption.

Through the development of this work, an electrical current of $50 \mathrm{~W}$ was used. [16,18-20] found that at a higher voltage $(>30 \mathrm{~V})$, the time was reduced $(<10 \mathrm{~min})$. This occurs due to an increase in the number of free ions from the sacrificial electrode, which accelerates the shift of cell-surface charges, allowing for faster flocculation.

Another variable that directly affected the efficiency was the distance between the electrodes. All the experiments performed employed a length of $5 \mathrm{~mm}$, which, according to [16], is an optimal distance to increase the efficiency of the process and reduce the time. According to [21], distances less than $10 \mathrm{~mm}$ affect the formation of gas bubbles around the electrode, and more considerable distances can negatively affect the overall efficiency and increase energy consumption. Optimization by Response Surface Methodology can lead to the best results [22-24]

Another crucial factor is the electrode material. Table 3 presents a short review of different materials employed for the harvesting of algae and cyanobacteria. The most common material is aluminum. Other materials, such as graphite, require the addition of electrolytes or chemical flocculants, such as $\mathrm{Al}_{2}\left(\mathrm{SO}_{4}\right)_{3}$ or chitosan, to achieve higher efficiencies $(>92 \%)[4,16]$. 
Table 3. Electrode materials evaluated for the harvesting of microalgae and cyanobacteria.

\begin{tabular}{|c|c|c|c|c|c|c|c|c|}
\hline Strain & Electrode Material & $\begin{array}{l}\text { Working } \\
\text { Volume (L) }\end{array}$ & $\begin{array}{c}\text { Biomass } \\
\text { Concentration }(\mathrm{g} / \mathrm{L})\end{array}$ & \# of Electrodes & Mixing (rpm) & Time(min) & Efficiency (\%) & Author \\
\hline Chlorella sp. MJ 11/11 & Stainless steel & 0.4 & 1.5 & 2 & - & 30 & 98 & [1] \\
\hline Chlorella sp. 0217 & Graphite coupled with chitosan & 1 & 0.5 & 2 & 30 & 3 & 90 & [16] \\
\hline Chlorella sp. (PTCC 6010) & 1 & 1.28 & - & 4 & $\begin{array}{l}100 \text { (high), } 30 \\
\quad \text { (low) }\end{array}$ & $\begin{array}{l}1 \text { (high), } 15 \\
\text { (low) }\end{array}$ & 96.8 & [5] \\
\hline Chlorella pyrenoidosa & $\begin{array}{c}\mathrm{Al}, \mathrm{Zn}, \mathrm{Cu}, \mathrm{Fe} \text {. and } \\
\text { non-sacrificial carbon electrode }\end{array}$ & 0.6 & $2.2 \pm 0.15$ & $\begin{array}{c}3 \\
\text { (2 cathodes, } 1 \\
\text { anode) }\end{array}$ & (100) & $(10 w)$ & 95.83 & [25] \\
\hline Chlorella vulgaris & $\mathrm{Al}$ & 0.4 & - & 2 & - & 8 & 100 & {$[8]$} \\
\hline Chlorella vulgaris UTEX 1803 & $\mathrm{Al}$ and $\mathrm{Cu}$ & 0.5 & 0.9 & 2 & 200 & 25 & $97-88$ & [13] \\
\hline Chlorella vulgaris & $\begin{array}{c}\mathrm{Al} \text { or } \mathrm{Fe} \text { (Anode), and } \mathrm{IrO}_{2} / \mathrm{TiO}_{2} \\
\text { (cathode) }\end{array}$ & 1 & 0.5 & 2 & - & 30 & 88 & [26] \\
\hline Desmodesmus subspicatus & $\mathrm{Al}$ or Fe Spiral electrode & - & - & - & - & 20 & 95.4 & [27] \\
\hline Dunaliella bardawil 30861 & Al coupled with sand & 0.2 & 0.88 & 2 & 150 & 3 & 97.16 & [3] \\
\hline Dunaliella salina & $\mathrm{Al}$ & 0.3 & - & 2 & 100 & 7 & 98.9 & [15] \\
\hline Microcystis aeruginosa & $\mathrm{Al}$ & 1 & - & 2 & 200 & 45 & 100 & [19] \\
\hline Microcystis aeruginosa & $\mathrm{Al}$ and $\mathrm{Fe}$ & 1 & - & 2 & 200 & 50 & 100 & [20] \\
\hline Phaeodactylum tricornutum & $\begin{array}{c}\mathrm{Al} \text { or } \mathrm{Fe} \text { (Anode), and } \mathrm{IrO}_{2} / \mathrm{TiO}_{2} \\
\text { (cathode) }\end{array}$ & 1 & 0.5 & 2 & - & 20 & 85 & [26] \\
\hline Scenedesmus sp. & $\mathrm{Al}$ and graphite & 0.34 & 0.25 & 2 & - & 20 & $98.5-92$ & [17] \\
\hline Scenedesmus acuminatus & $\mathrm{Mg}, \mathrm{Al}, \mathrm{Zn}, \mathrm{Cu}, \mathrm{Fe}$, and brass & 0.09 & - & 2 & 100 & $7.3-30.9$ & 90 & [18] \\
\hline $\begin{array}{l}\text { Scenedesmus obliquus } \\
\text { FR751179.1 }\end{array}$ & Graphite mixed with $\mathrm{Al}_{2}\left(\mathrm{SO}_{4}\right)_{3}$ & 0.9 & 2.4 & $\begin{array}{c}3 \\
\text { (2 cathodes, } 1 \\
\text { anode) }\end{array}$ & - & 60 & 83 & {$[4]$} \\
\hline Tetraselmis sp. & $\mathrm{Al}$ & 4.8 & - & 2 & - & 15 & - & [6] \\
\hline Scenedesmus sp. UFPS_002 & $\mathrm{Al}$ & 2 & 1.2 & 11 & 150 & 15 & 100 & This paper \\
\hline
\end{tabular}




\section{Conclusions}

The present work explored the interaction between critical variables (mixing, number of electrodes and time) for the efficient concentration and harvesting of microalgal biomass through an electroflotation process. Results showed that time could be significantly reduced (from 30 to $15 \mathrm{~min}$ ) as long as the ten or more electrodes were active and medium mixing rates $(150 \mathrm{rpm})$ were used. From the data, the innovative equipment had a lower-medium cost (260 USD), with cheap and resistant materials that anyone can build. This new configuration proves that the electrodes can be reused several times, which in turn reduces the cost of the concentration for up to $2 \mathrm{~L}$ of algal suspension with a concentration of $1.1 \mathrm{~g} / \mathrm{L}$ of algal biomass. We hope this innovative approach can be used by different researchers to improve our knowledge of the concentration and harvesting of algae and cyanobacteria.

Author Contributions: Conceptualization, J.E.C.-R., I.Y.C.-G. and A.Z.; data curation, A.F.B.-S.; formal analysis, J.B.G.-M. and A.Z.; funding acquisition, E.M.S.-G. and A.F.B.-S.; investigation, J.E.C.-R., I.Y.C.-G. and E.M.S.-G.; methodology, J.B.G.-M., A.F.B.-S. and A.Z.; project administration, A.F.B-S.; resources, J.E.C.-R., I.Y.C.-G. and E.M.S.-G.; software, J.B.G.-M. and E.M.S.-G.; supervision, A.F.B.-S. and A.Z.; validation, J.E.C.-R. and I.Y.C.-G.; visualization, A.F.B.-S. and A.Z.; writing-original draft, A.F.B.-S. and A.Z.; writing-review and editing, J.B.G.-M., A.F.B.-S. and A.Z. All authors have read and agreed to the published version of the manuscript.

Funding: The Gen Foundation funded this research with the "Isolation of thermotolerant algae as a novel source of food colorants" project, as did the Universidad Francisco de Paula Santander Internal Research funding (FINU 27-2019). The Universidad de Santander (UDES) funded the APC.

Acknowledgments: We would like to express our sincere gratitude to Eng. M.A. Castellanos-Estupiñan for the design and construction of aluminum electrodes; to the Universidad de Santander (UDES) for covering the expenses of scientific editing and the APC; to the Universidad Francisco de Paula Santander for providing the equipment for this research; and to the Colombian Ministry of Science, Technology and Innovation (MINCIENCIAS) for the support for national $\mathrm{PhD}$ doctorates through the Francisco José de Caldas scholarship program and the young researchers" “Jovenes Investigadores e Innovadores” scholarship program.

Conflicts of Interest: The authors declare no conflict of interest. 
Appendix A

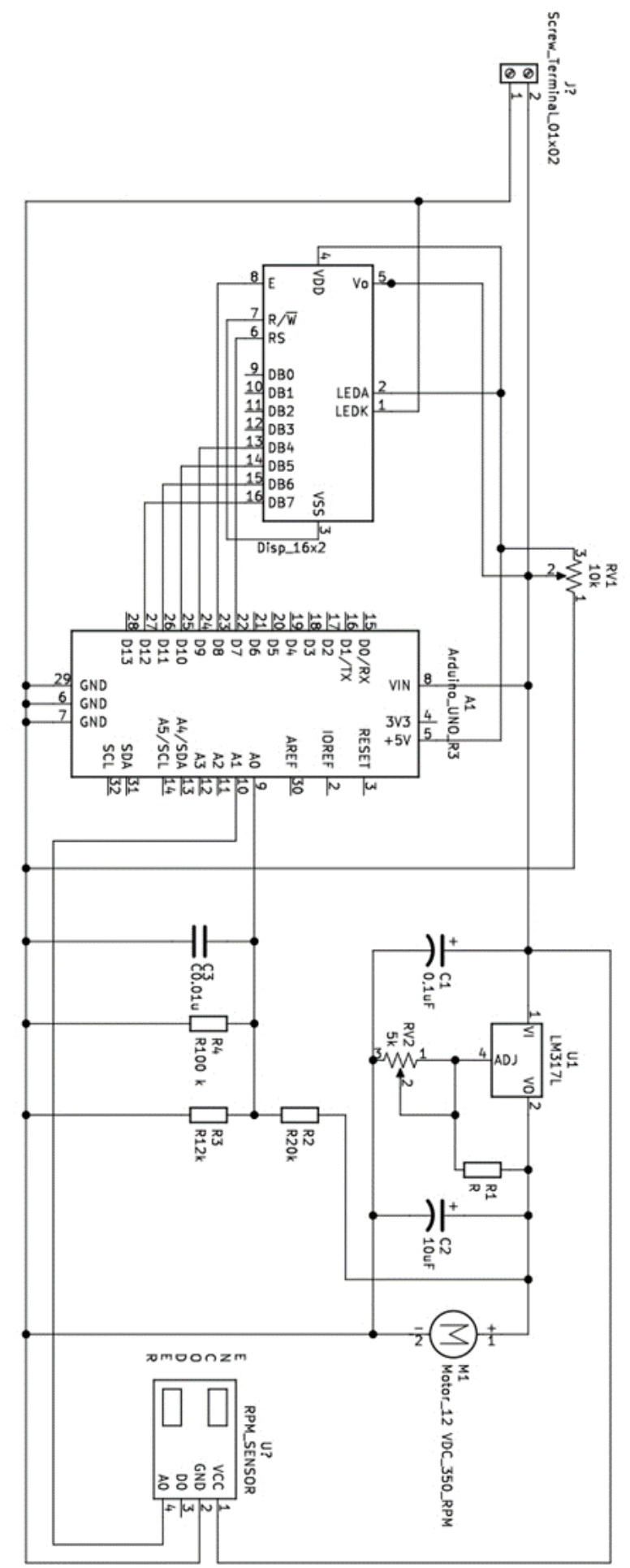

Figure A1. Magnetic Stirrer with Speed Control. 


\section{Appendix B}

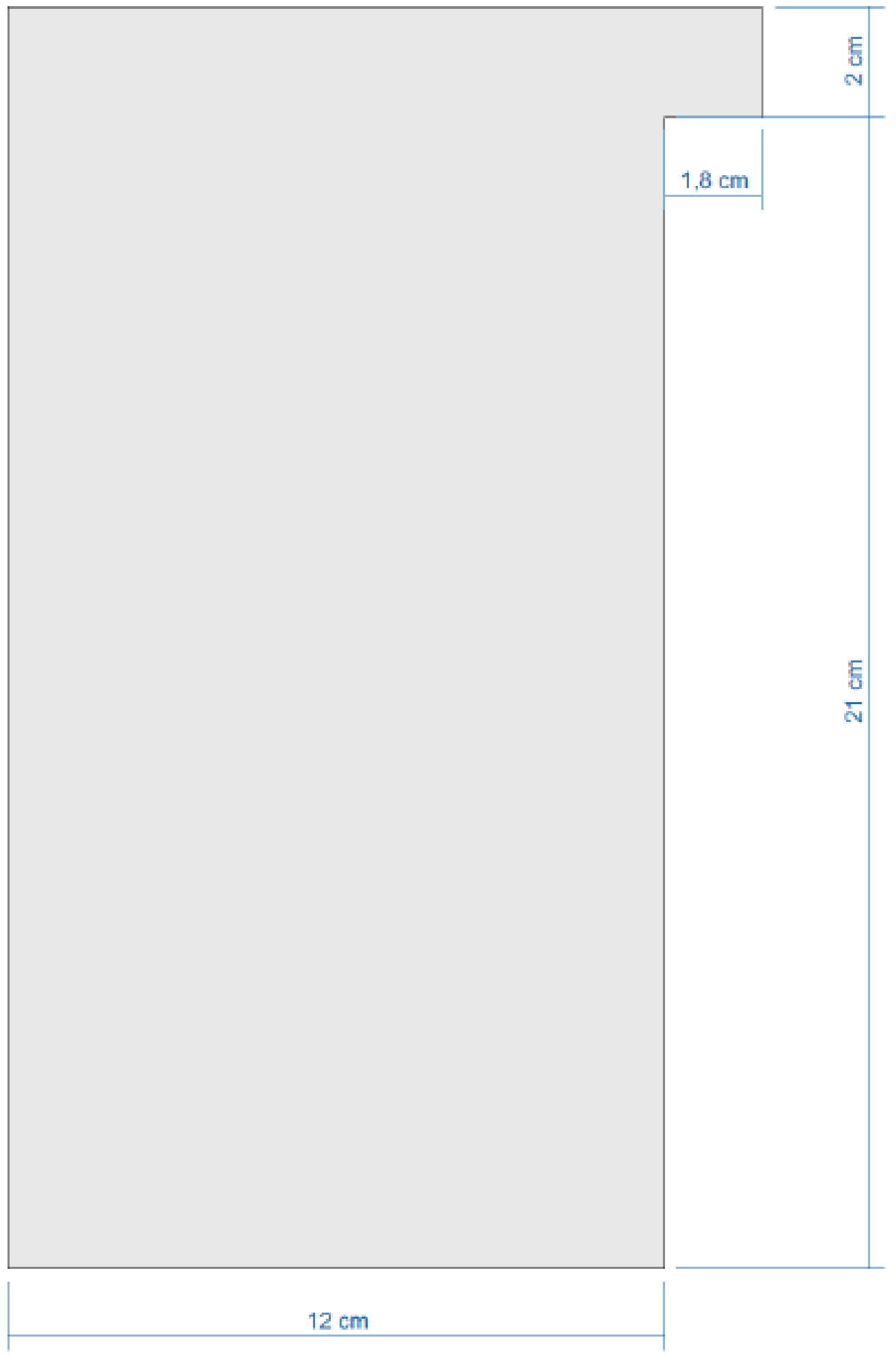

Figure A2. Electrode Design. Note: Each electrode was built using $0.1 \mathrm{~cm}$ thick aluminum plates. 


\section{Appendix C}
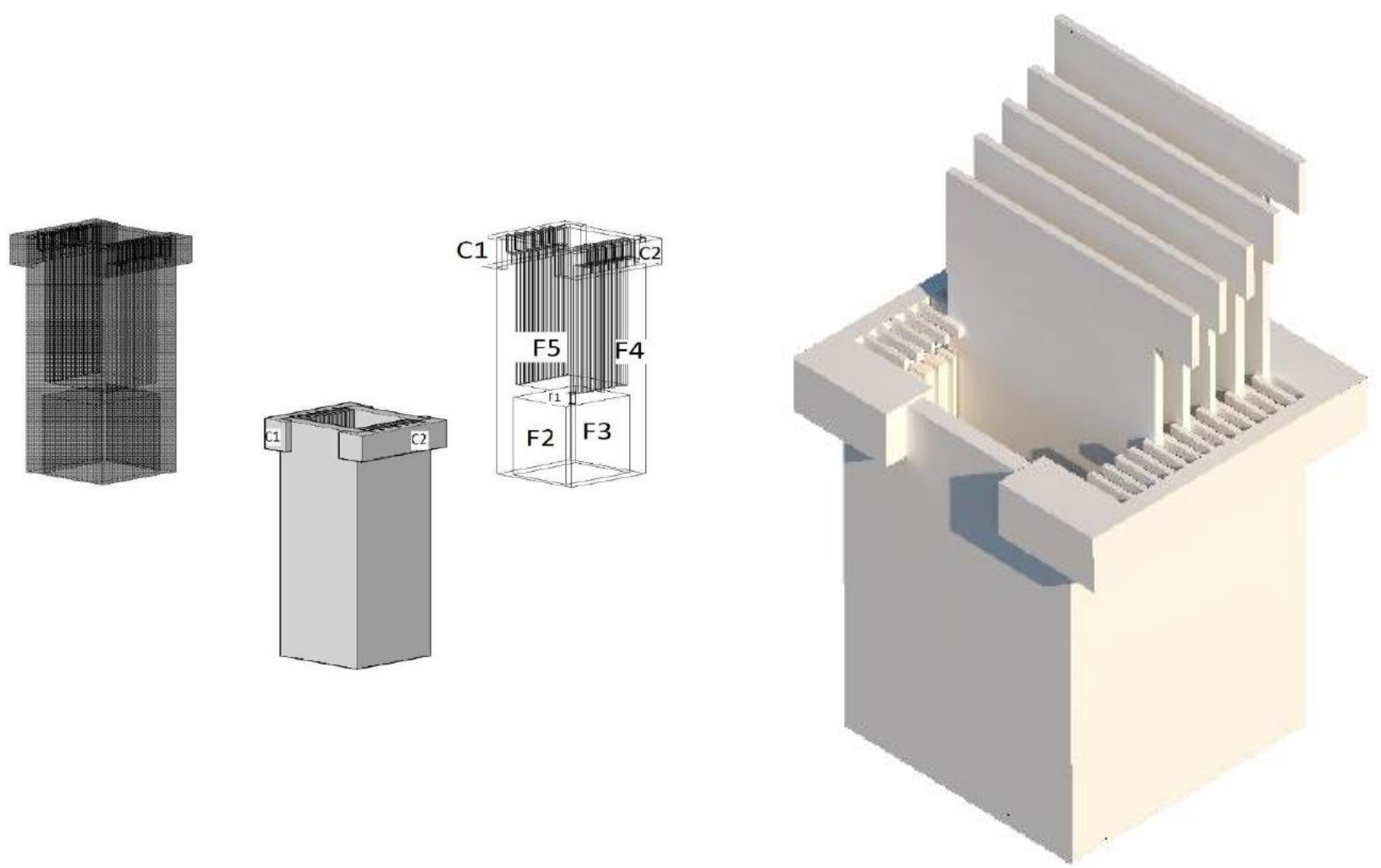

Figure A3. Assembly of the Equipment with the Electrodes. 
Appendix D
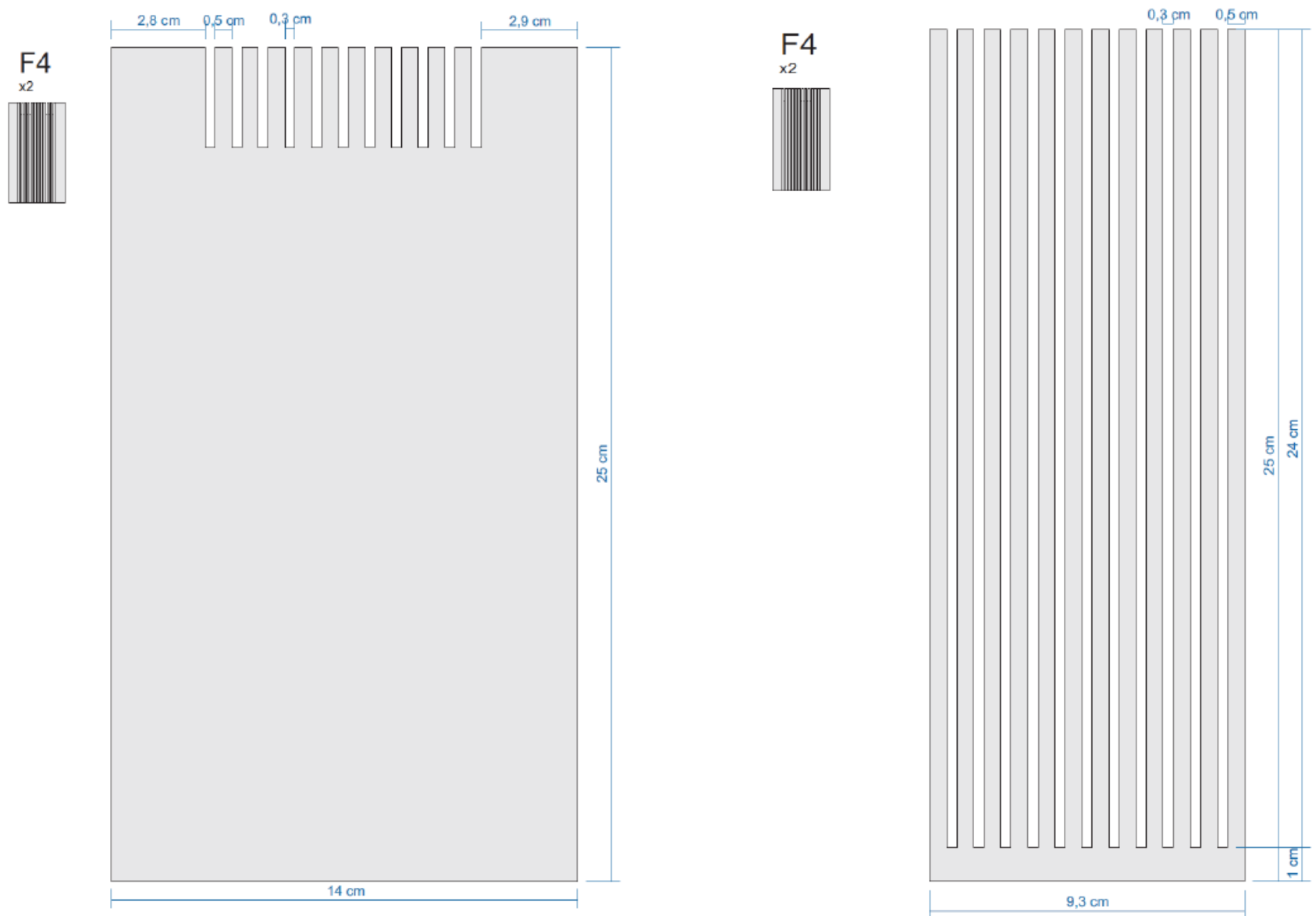

Figure A4. Cont. 

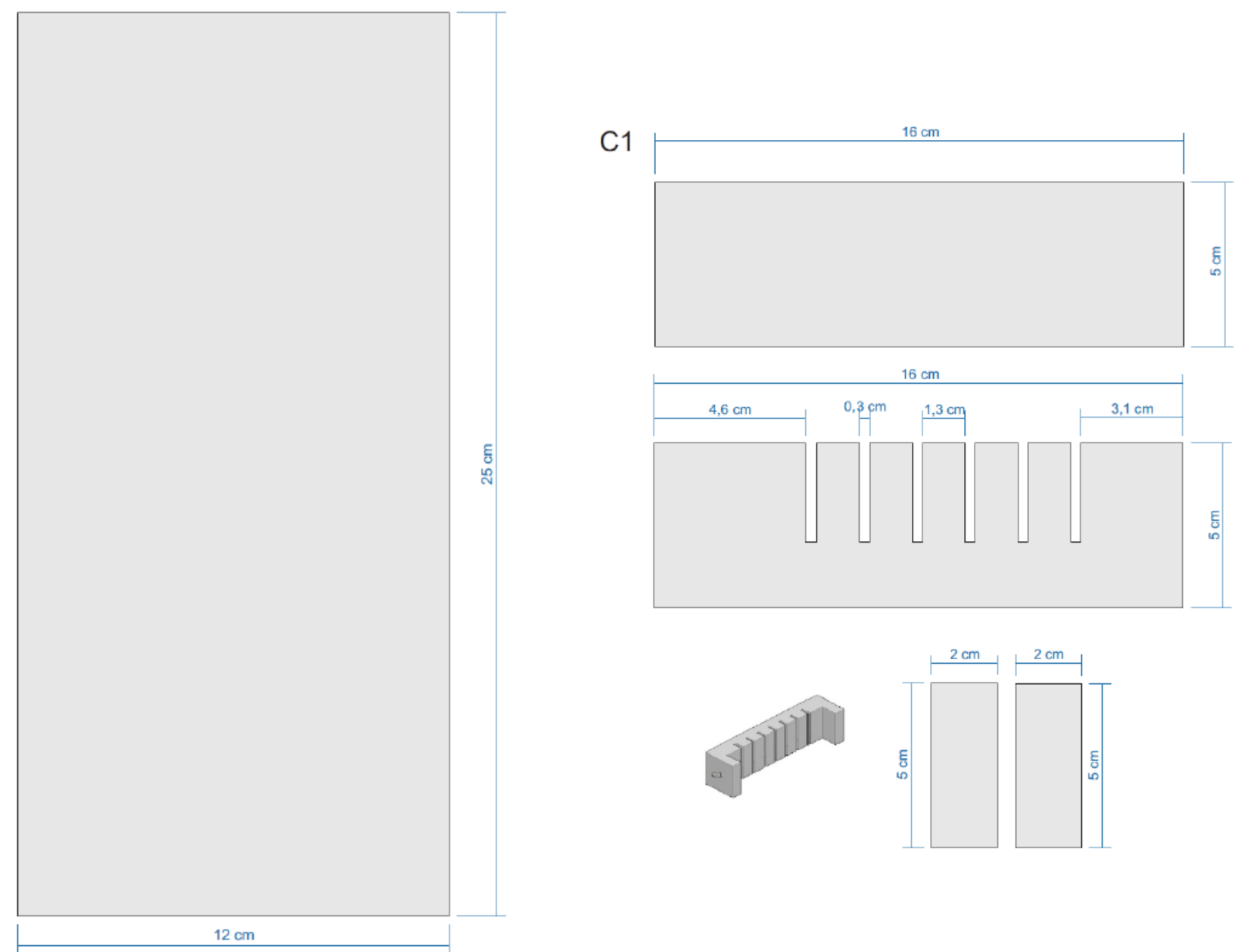

Figure A4. Cont. 


\section{C2}

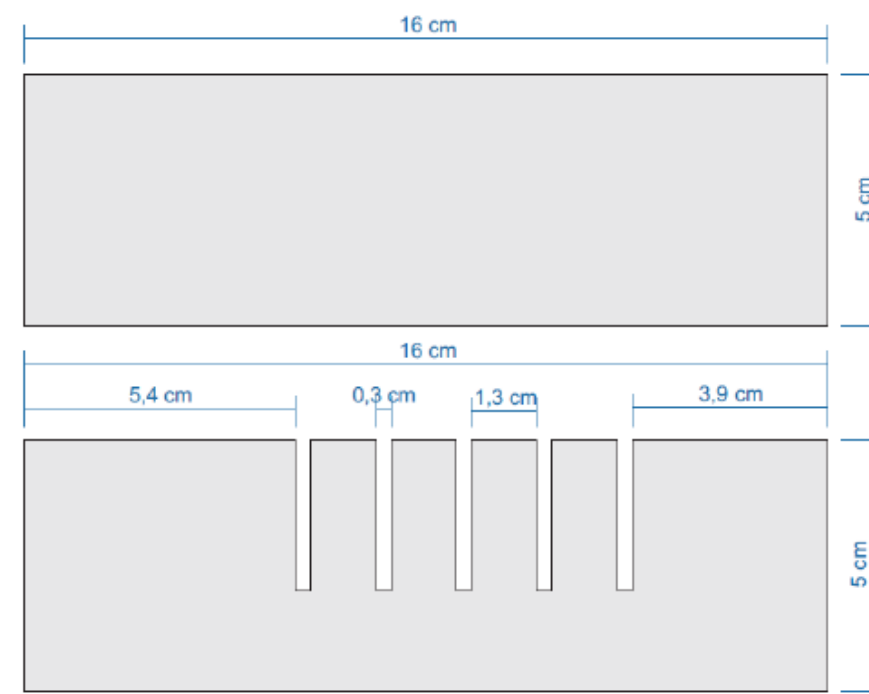

F1
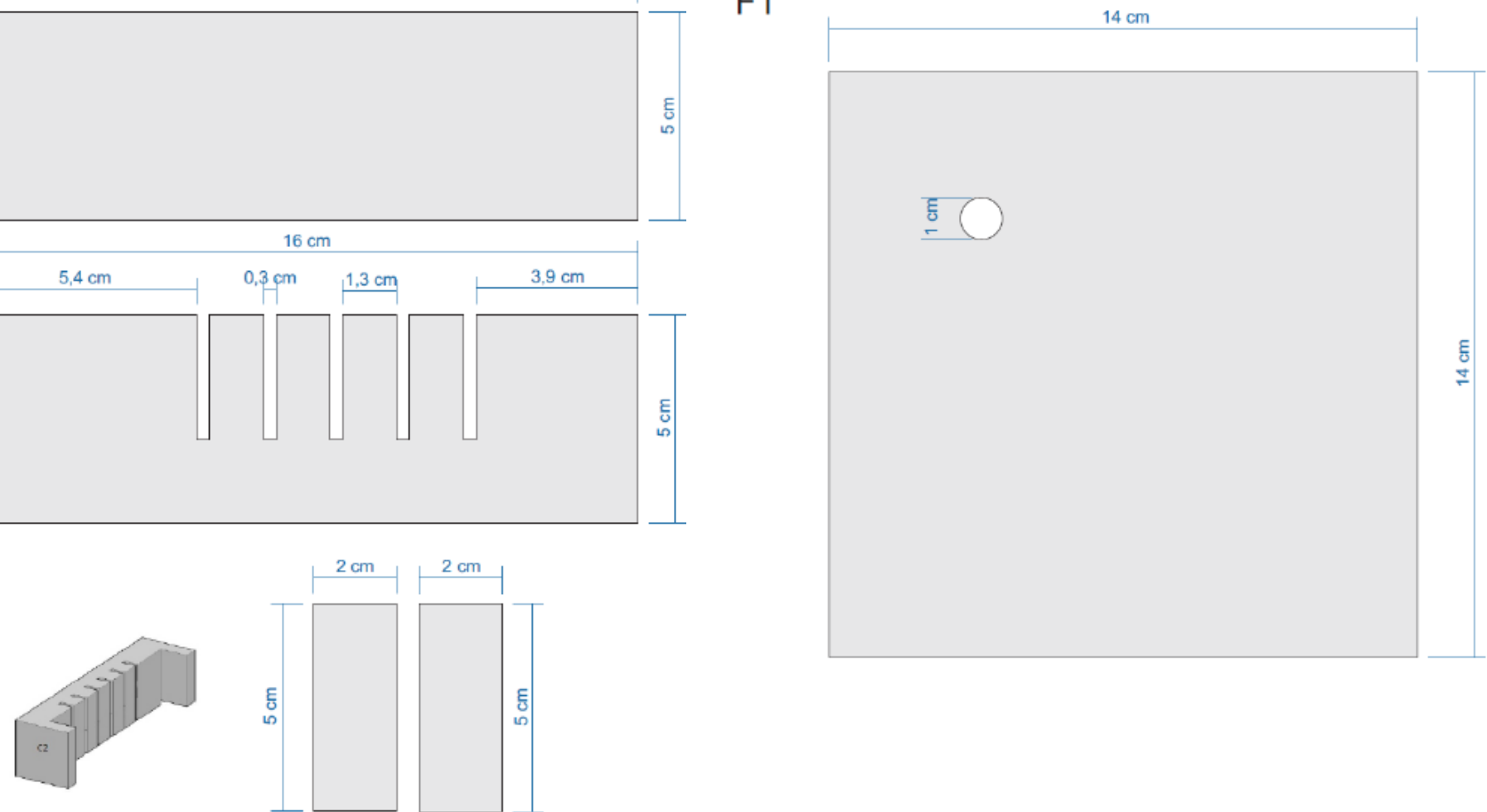

Figure A4. Cont. 
$\mathrm{F} 2$

$\mathrm{x}^{2}$

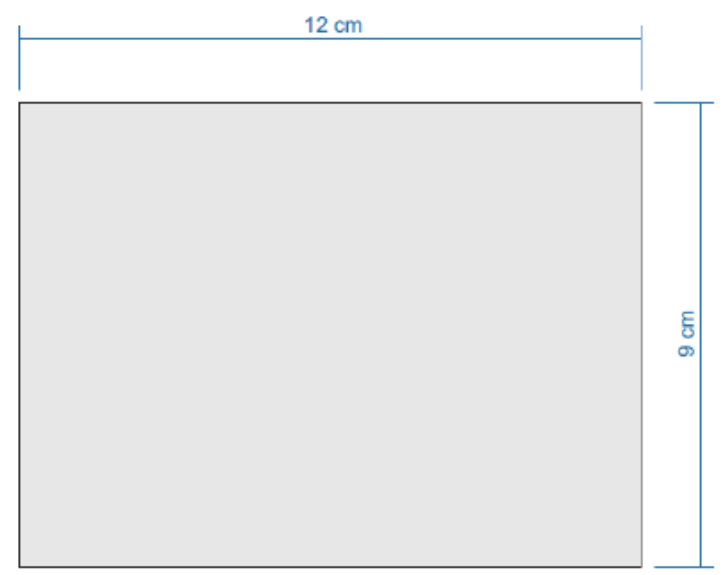

F3

$\times 2$

$14 \mathrm{~cm}$

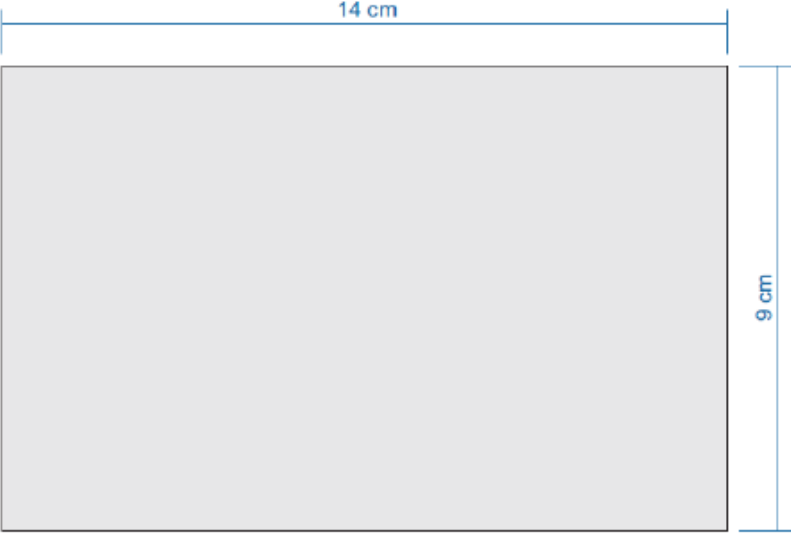

Figure A4. Sections of the Equipment. 


\section{Appendix E}

Table A1. Cost and Source of Materials for the Construction of the Equipment.

\begin{tabular}{|c|c|c|c|c|c|c|c|c|}
\hline \multirow{2}{*}{$\begin{array}{c}\text { Reference Description } \\
\text { Electroflotation }\end{array}$} & Article & \multicolumn{2}{|c|}{ Quantity } & \multicolumn{2}{|c|}{ Unit Cost (USD) } & \multicolumn{2}{|c|}{ Total Price (USD) } & \multirow{6}{*}{$\begin{array}{c}\begin{array}{c}\text { Source of } \\
\text { Materials }\end{array} \\
\text { Local supplier } \\
\text { Local supplier } \\
\text { Local supplier } \\
\text { Local supplier }\end{array}$} \\
\hline & Acrylic & 1.5 & $\mathrm{~m}^{2}$ & 55.84 & $\mathrm{~m}^{2}$ & & 83.76 & \\
\hline & Wire caliber18 & 2 & $\mathrm{~m}$ & 1.01 & $\mathrm{~m}$ & & 2.02 & \\
\hline & Connectors banana plug & 2 & $\mathrm{ud}$ & 0.30 & ud & & 0.60 & \\
\hline & Cutting and assembly & & & 34.72 & & & 34.72 & \\
\hline & & & & & & Subtotal & 121.10 & \\
\hline \multirow[t]{7}{*}{ mixing } & Arduino ${ }^{\circledR}$ NANO & 1 & $\mathrm{ud}$ & 3.47 & ud & & 3.47 & shorturl.at/hEU09 \\
\hline & LCD $16 \times 2$ & 1 & $\mathrm{ud}$ & 6.99 & ud & & 6.99 & shorturl.at/gyCYZ \\
\hline & Neodymium magnet & 2 & $\mathrm{ud}$ & 8.99 & $\mathrm{ud}$ & & 8.99 & shorturl.at/yzBLM \\
\hline & L298N & 1 & $\mathrm{ud}$ & 3.76 & ud & & 3.76 & shorturl.at/npRX9 \\
\hline & Potentiometer 10k & 1 & $\mathrm{ud}$ & 8.99 & $\mathrm{ud}$ & & 8.99 & shorturl.at/afryO \\
\hline & Motor Mh7 300 RPMs & 1 & $\mathrm{ud}$ & 15.99 & ud & & 15.99 & shorturl.at/jvBJO \\
\hline & & & & & & Subtotal & 48.19 & \\
\hline \multirow[t]{6}{*}{ Accessories } & Magnetic stir bar & 1 & $\mathrm{ud}$ & 3.47 & $\mathrm{ud}$ & & 3.47 & Local supplier \\
\hline & Aluminum sheets & 0.3234 & $\mathrm{~m}^{2}$ & 33.27 & $\mathrm{~m}^{2}$ & & 10.75 & Local supplier \\
\hline & Aluminum sheets cut & 11 & $\mathrm{ud}$ & 0.10 & $\mathrm{ud}$ & & 1.10 & Local supplier \\
\hline & 0-50 V Power Supply Stabilizer Module 15 A 750 W & 1 & ud & 48.03 & ud & & 75.00 & shorturl.at/GOT27 \\
\hline & & & & & & Subtotal & 90.32 & \\
\hline & & & & & & TOTAL & 259.61 USD & \\
\hline
\end{tabular}




\section{References}

1. Lal, A.; Ghosh, S.; Das, D. Improvement in electrically induced biomass harvesting of Chlorella sp. MJ 11/11 for bulk biomass production. J. Appl. Phycol. 2018, 30, 979-993. [CrossRef]

2. Ummalyma, S.B.; Mathew, A.K.; Pandey, A.; Sukumaran, R.K. Harvesting of microalgal biomass: Efficient method for flocculation through pH modulation. Bioresour. Technol. 2016, 213, 216-221. [CrossRef] [PubMed]

3. Xiong, Q.; Pang, Q.; Pan, X.; Chika, A.O.; Wang, L.; Shi, J.; Jia, L.; Chen, C.; Gao, Y. Facile sand enhanced electro-flocculation for cost-efficient harvesting of Dunaliella salina. Bioresour. Technol. 2015, 187, 326-330. [CrossRef]

4. Misra, R.; Guldhe, A.; Singh, P.; Rawat, I.; Stenström, T.A.; Bux, F. Evaluation of operating conditions for sustainable harvesting of microalgal biomass applying electrochemical method using non sacrificial electrodes. Bioresour. Technol. 2015, 176, 1-7. [CrossRef] [PubMed]

5. Golzary, A.; Imanian, S.; Abdoli, M.A.; Khodadadi, A.; Karbassi, A. A cost-effective strategy for marine microalgae separation by electro-coagulation-flotation process aimed at bio-crude oil production: Optimization and evaluation study. Sep. Purif. Tech. 2015, 147, 156-165. [CrossRef]

6. Lee, A.K.; Lewis, D.M.; Ashman, P.J. Harvesting of marine microalgae by electroflocculation: The energetics, plant design, and economics. Appl. Energy 2013, 108, 45-53. [CrossRef]

7. Marrone, B.L.; Lacey, R.E.; Anderson, D.B.; Bonner, J.; Coons, J.; Dale, T.; Downes, C.M.; Fernando, S.; Fuller, C.; Goodall, B.; et al. Review of the harvesting and extraction program within the National Alliance for Advanced Biofuels and Bioproducts. Algal. Res. 2017, 33, 470-485. [CrossRef]

8. Shi, W.; Zhu, L.; Chen, Q.; Lu, J.; Pan, G.; Hu, L.; Yi, Q. Synergy of flocculation and flotation for microalgae harvesting using aluminium electrolysis. Bioresour. Technol. 2017, 233, 127-133. [CrossRef] [PubMed]

9. Đukić, A.; Firak, M. Hydrogen production using alkaline electrolyzer and photovoltaic (PV) module. Int. J. Hydrog. Energy 2011, 36, 7799-7806. [CrossRef]

10. Mollaha, M.Y.A.; Morkovsky, P.; Gomes, J.A.G.; Kesmez, M.; Parga, J.; Cocke, D.L. Fundamentals, present and future perspectives of electrocoagulation. J. Hazard. Mater. 2004, 114, 199-210. [CrossRef]

11. Emamjomeh, M.M.; Sivakumar, M. An empirical model for defluoridation by batch monopolar electrocoagulation/flotation (ECF) process. J. Hazard. Mater. 2006, 131, 118-125. [CrossRef]

12. Gamage, N.P.; Rimer, J.D.; Chellam, S. Improvements in permeate flux by aluminum electroflotation pretreatment during microfiltration of surface water. J. Membr. Sci. 2012, 411-412, 45-53. [CrossRef]

13. Castellaños-Estupiñan, M.A.; Sánchez-Galvis, E.M.; García-Martínez, J.B.; Barajas-Ferreira, C.; Zuorro, A.; Barajas-Solano, A.F. Design of an electroflotation system for the concentration and harvesting of freshwater microalgae. Chem. Eng. Trans. 2018, 64, 1-6.

14. Andersen, R.A.; Berges, J.A.; Harrison, P.J.; Watanabe, M.M. Appendix A-Recipes for Freshwater and Seawater Media. In Algal Culturing Techniques; Andersen, R.A., Ed.; Elsevier Academic Press: Burlington, MA, USA, 2005; pp. 429-538.

15. Zenouzi, A.; Ghobadian, B.; Hejazi, M.A.; Rahnemoon, P. Harvesting of microalgae Dunaliella salina using electroflocculation. J. Agric. Sci. Technol. 2013, 15, 879-888.

16. Zhou, W.; Gao, L.; Cheng, W.; Chen, L.; Wang, J.; Wang, H.; Zhang, W.; Liu, T. Electro-flotation of Chlorella sp. assisted with flocculation by chitosan. Algal. Res. 2016, 18, 7-14. [CrossRef]

17. Liu, S.; Abu Hajar, H.A.; Riefler, G.; Stuart, B.J. Investigation of electrolytic flocculation for microalga: Scenedesmus sp. using aluminum and graphite electrodes. RSC. Adv. 2018, 8, 38808-38817. [CrossRef]

18. Bleeke, F.; Quante, G.; Winckelmann, D.; Klöck, G. Effect of voltage and electrode material on electroflocculation of Scenedesmus acuminatus. Bioresour. Bioprocess. 2015, 2, 1-8. [CrossRef]

19. Gao, S.; Du, M.; Tian, J.; Yang, J.; Yang, J.; Ma, F.; Nan, J. Effects of chloride ions on electro-coagulation-flotation process with aluminum electrodes for algae removal. J. Hazard. Mater. 2010, 182, 827-834. [CrossRef]

20. Gao, S.; Yang, J.; Tian, J.; Ma, F.; Tu, G.; Du, M. Electro-coagulation-flotation process for algae removal. J. Hazard. Mater. 2010, 177, 336-343. [CrossRef]

21. Chatsungnoen, T.; Chisti, Y. Flocculation and electroflocculation for algal biomass recovery. In Biofuels from Algae, 2nd ed.; Pandey, A., Chang, S., Soccol, C., Lee, D., Chisti, Y., Eds.; Elsevier: Amsterdam, The Netherlands, 2019; Volume 1, pp. 257-286. 
22. Maffei, G.; Bracciale, M.P.; Broggi, A.; Zuorro, A.; Santarelli, M.L.; Lavecchia, R. Effect of an enzymatic treatment with cellulase and mannanase on the structural properties of Nannochloropsis microalgae. Bioresour. Technol. 2018, 249, 592-598. [CrossRef]

23. Lavecchia, R.; Medici, F.; Patterer, M.S.; Zuorro, A. Lead removal from water by adsorption on spent coffee grounds. Chem. Eng. Trans. 2016, 47, 295-300.

24. Fidaleo, M.; Zuorro, A.; Lavecchia, R. Antimicrobial activity of some italian honeys against pathogenic bacteria. Chem. Eng. Trans. 2011, 47, 295-300.

25. Rahmani, A.; Zerrouki, D.; Djafer, L.; Ayral, A. Hydrogen recovery from the photovoltaic electroflocculation-flotation process for harvesting Chlorella pyrenoidosa microalgae. Int. J. Hyd. Energy 2017, 42, 19591-19596. [CrossRef]

26. Baierle, F.; John, D.; Souza, M.; Bjerk, T.; Moraes, M.; Hoeltz, M.; Rohlfej, A.; Camargo, M.; Corbellini, V.; Schneider, R. Biomass from microalgae separation by electroflotation with iron and aluminum spiral electrodes. Chem. Eng. J. 2015, 267, 274-281. [CrossRef]

27. Vandamme, D.; Pontes, S.C.V.; Goiris, K.; Foubert, I.; Pinoy, L.J.J.; Muylaert, K. Evaluation of electro-coagulation-flocculation for harvesting marine and freshwater microalgae. Biotechnol. Bioeng. 2011, 108, 2320-2329. [CrossRef]

(C) 2020 by the authors. Licensee MDPI, Basel, Switzerland. This article is an open access article distributed under the terms and conditions of the Creative Commons Attribution (CC BY) license (http://creativecommons.org/licenses/by/4.0/). 